\title{
Ecologists and the development of sustainability curricula for majors vs. non-majors
}

\section{Carmen R. Cid}

\section{Professor of Ecology}

Dean - School of Arts and Sciences

Eastern Connecticut State University 


\section{Infusing ecology into and developing sustainability curricula}

Why should ecologists be leaders in developing sustainability curricula?

What is easily doable?

What has and is being done?

What else can ecologists do? 
USA Trob49 $\quad g_{13 / 109}$

\section{Sustainability could secure a good future}

College students flock to 'green' degrees, careers

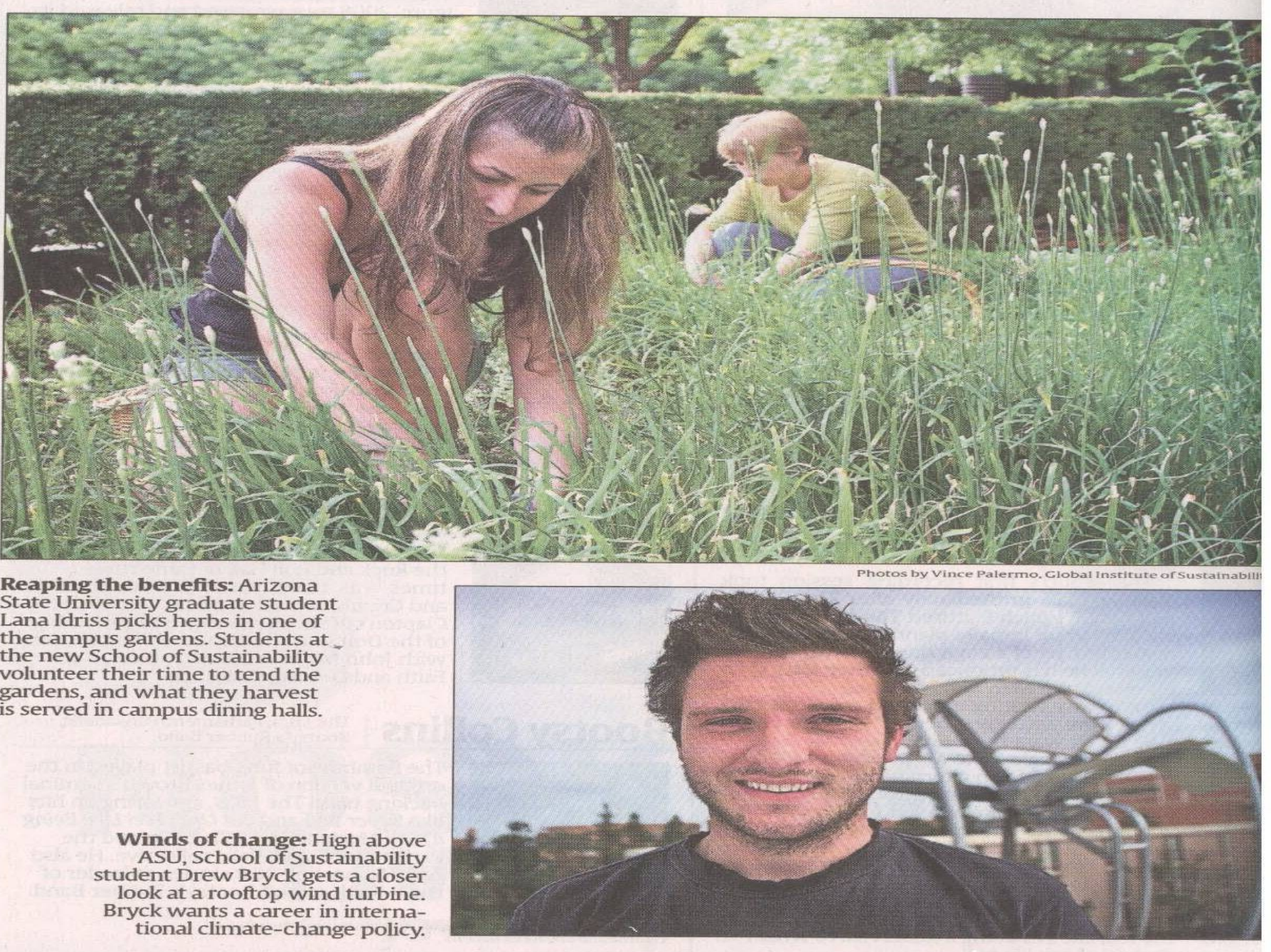

Incentives to develop sustainability curricula

August 3, 2009 USA TODAY Article

Highlighting Arizona State Univ.

See http://www.ulsf org/resources_sust_ degrees.htm

http://www.aashe. org/ resources/programs. php

For other programs 


\section{gor rebar.}

a

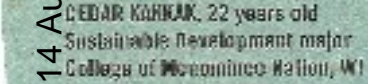
Olikked an wild rime and D):atainahility:

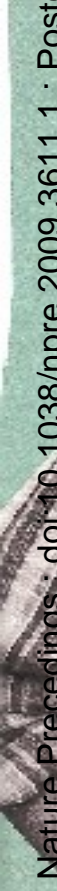

ath $x^{2}+2$
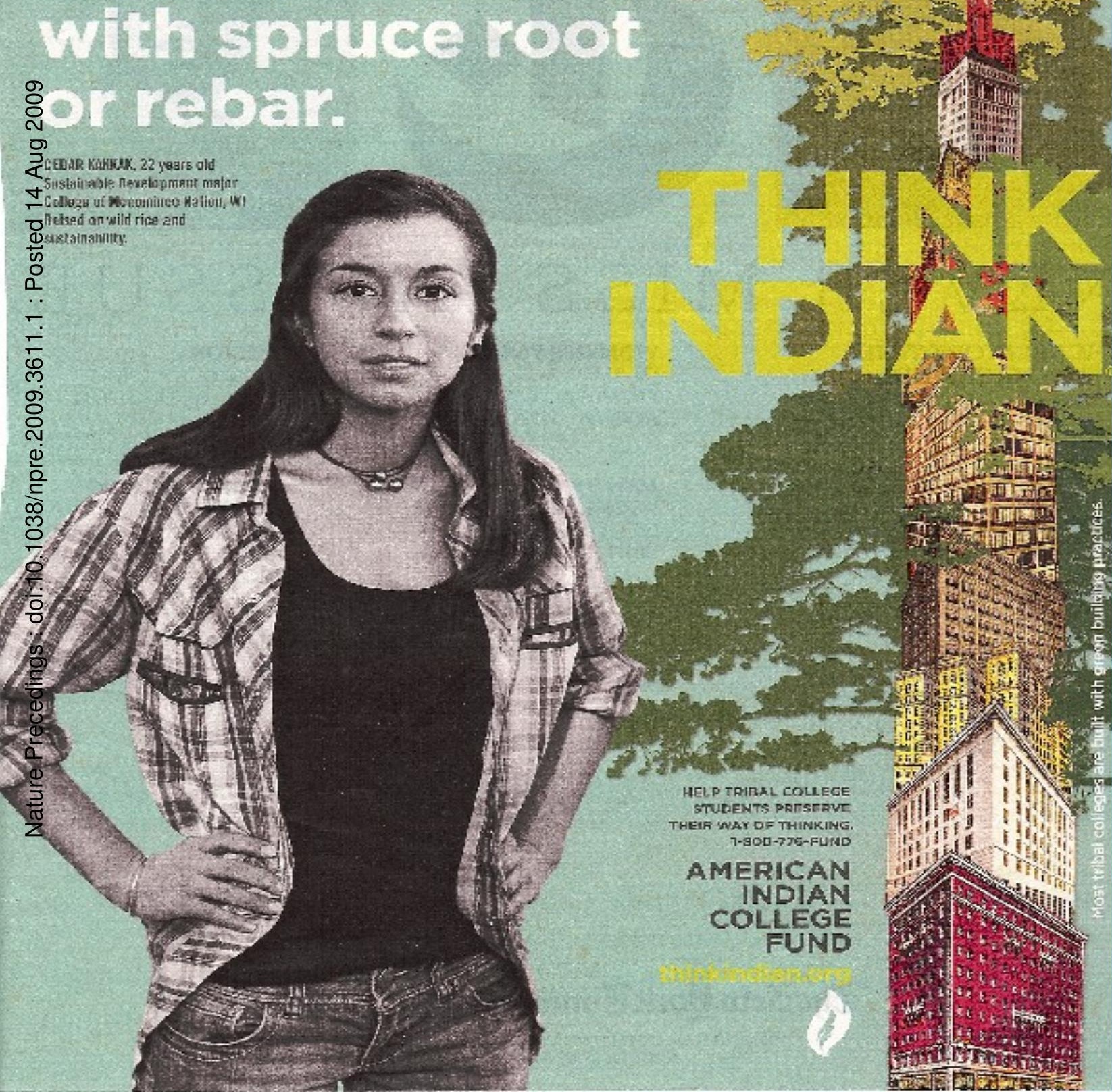
Incentives for Higher Education Institutions to Develop Sustainability
Curricula

THE PRINCETON REVIEW GIVES 697 COLLEGES "GREEN" RATINGS IN NEW 2010 EDITIONS OF ITS ANNUAL COLLEGE GUIDES AND WEBSITE PROFILES OF SCHOOLS - July 27, 2009

- Rating Scores Based on Environmental Practices, Policies and Course Offerings

- Green Honor Roll Salutes 15 Colleges Receiving Highest Rating Score of 99

http://www.princetonreview.com/green/press-release.aspx 
American Association of State Colleges and Universitjes

A Higher Education Policy Brief •

$$
\text { June } 2008
$$

\section{The State College Role in Advancing Environmental Sustainability: Policies, Programs and Practices} By Thomas Harnisch, Research Associate 


\section{Table 1. Leading the way toward sustainability: An ecological mission for American universities}

\begin{tabular}{|c|c|c|c|}
\hline System & Goal & Reduce & Increase \\
\hline 畐ergy & Seek fossil fuel independence & Fossil fuels & Renewable energy \\
\hline Whter & Conserve water resources & Water waste & Water conservation \\
\hline 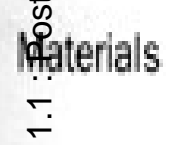 & End materials waste & Materials waste & Green procurement policies \\
\hline $\begin{array}{l}\text { Fingod } \\
8 \\
8\end{array}$ & Eat food produced sustainably & Industrialal, farfflung food system & Sustainable, more regional food system \\
\hline 望ind & Create and abide by a land ethic & Treatment of land as a commodity & Wise stewardship of land \\
\hline 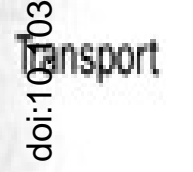 & $\begin{array}{l}\text { Create sustainable alternatives to } \\
\text { car-based transit }\end{array}$ & Car dependence/spraw & Public transit/compact settlement \\
\hline 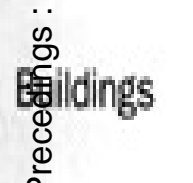 & Create "green" buildings & Conventional buildings & Ecological design \\
\hline 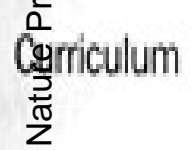 & Guarantee ecological literacy & Alienation from natural world & Comection to natural world \\
\hline Research & Prioritize research for a sustainable world & Research undermining sustainability & Research promoting sustainability \\
\hline
\end{tabular}

Uhl and Anderson 2001 BioScience - Urge higher ed. to guarantee ecological literacy 


\section{Factors favoring sustainability curriculum development}

Majors/minors and graduate programs developed in response to:

- Student demand and interest

- New and existing faculty research interests

- Increased need for maximizing use of existing University resources

- University mission focus on environmental stewardship and social responsibility

- National trends in higher education

- Resource-obtaining value to the University 


\section{Barriers to Sustainability Curriculum Development in Higher Ed.}

Curriculum requires collaboration across disciplines and must be problem-oriented Applied research focus may not relate to current faculty research interests

Departments may view interdisciplinary curriculum as "watering down" each discipline's major - especially if integrating non-science areas with the sciences

University may view interdisciplinary focus as problematic for management or assessment of success of faculty and programs 


\section{Political and Economic Conditions}

\section{Social-Ecological System}

\section{Social}

Processes

Demography

Livelihood activities

Communicating, educating

Health-seeking, well-being

SScience, technology, innovation ب̣̣. Economic development, trade

Policies, laws, contracts Visioning, missions Socio-political organization Power struggles Crises, governance Culture, beliefs, values

Human
Components
Individuals
Households
Communities
Institutions
Enterprises
Corporations
Villages, cities
Governments
Non-gov't orgs
Supranational bodies

\section{Integration}

Land/water/resource use Inputs, investments Resource depletion Resource renewal Planning Regulation Production Consumption Contamination Recycling, disposal Socio-ecological understanding Management practices

Experimentation Adaptation Mitigation

\section{Ecological} Processes Productivity Consumption Decomposition Energy flow Nutrient cycling Disturbances \& resilience Reproduction \& mortality Species interactions Pollination \& seed dispersal Animal movement Deposition \& erosion Evolution Climate change

\section{Ecosystems} Landscapes Watersheds
Populations

Soil

Water

Watershe 


\section{Process for developing sustainability curricula}

Put capable person(s) in charge of campus "sustainability" initiatives - curriculum, facilities, operations, outreach Infuse "sustainability" into General Education program coursework

Infuse "sustainability" into summer orientation and First Year Program courses

Develop interdisciplinary minor from existing courses with resource-management, development, globalization and environmental stewardship focus

Develop interdisciplinary majors - 4 ways 


\section{Approaches to Developing Interdisciplinary Majors}

Develop "Individualized Major" self-designed interdisciplinary model to use as way to pilot new majors

Develop Bachelor of General Studies interdisciplinary concentrations to market new careers to non-traditional students in the workforce

Develop tracks with interdisciplinary components in existing majors Reward faculty for interdisciplinary collaboration in curriculum development and research -- through grants, faculty release time, consideration in promotion and tenure process 
Sustainable Energy Studies at Eastern Connecticut State Univ.

Environmental Earth Science - leader dept.

Mlinor Program in

Sustajnable Energy

Studies

Major Program being

developed

Strong contribution to

General Education and

First Year Program

coursework

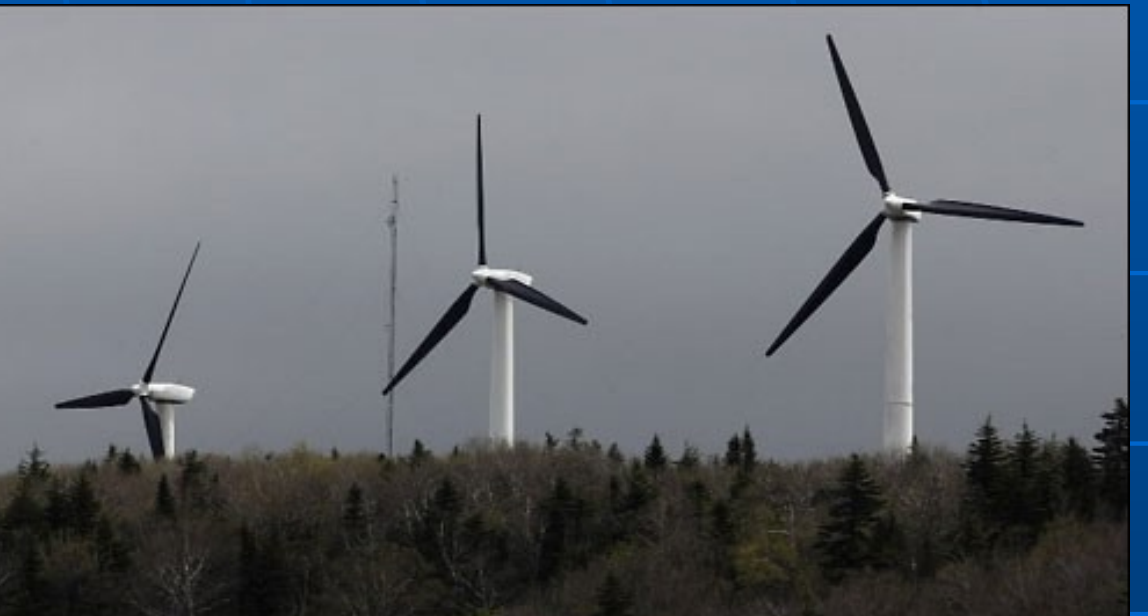




\section{Facilities and Administration Commitment}

LEED Certjfied Bujldjings

Recycling Program

Energy Conservation Program

Geothermal Heating and Cooling

Biodliesel Heating Project President's signing of Talloires Declaration and Institute of Sustainable Energy

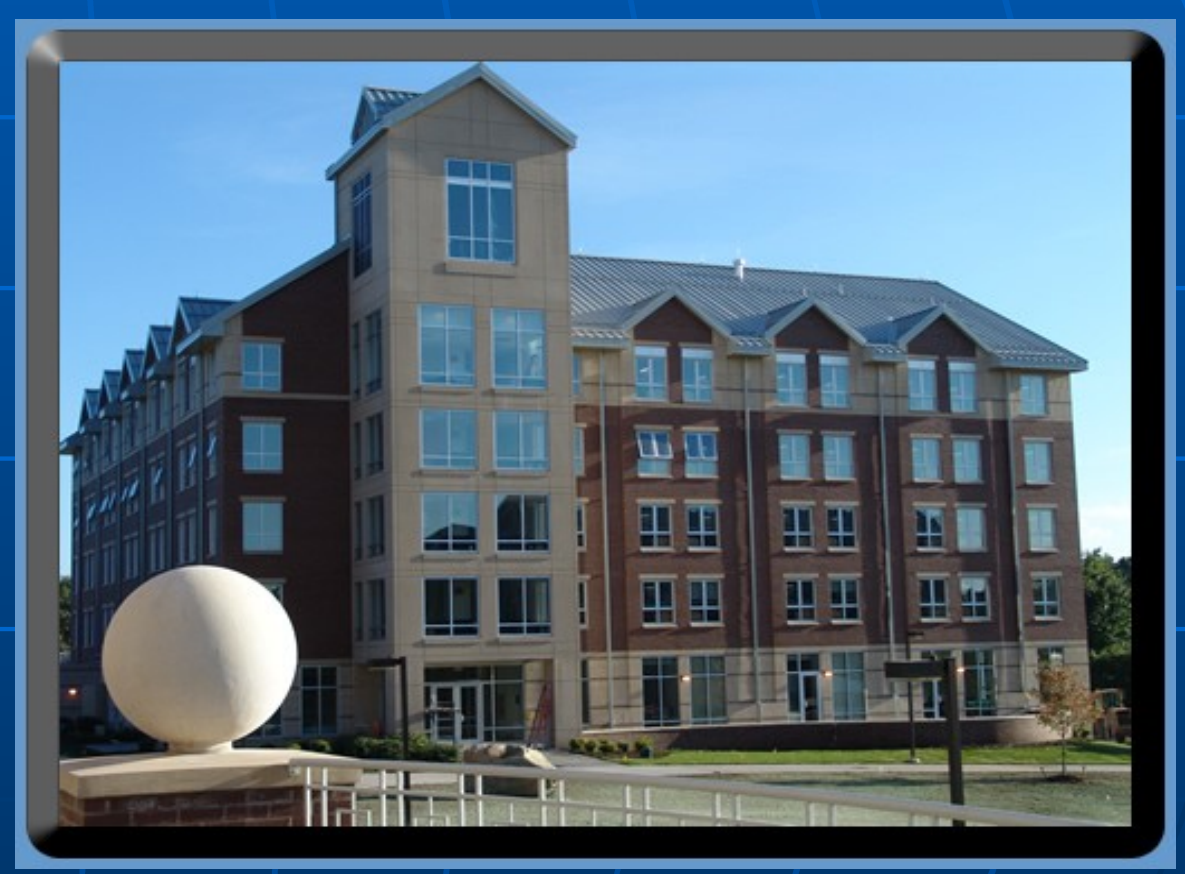




\section{Campus and Community as Sustainability Field Labs}

PV Lighting

Wind Turbine

Meteorological

instruments

Building sub-metering
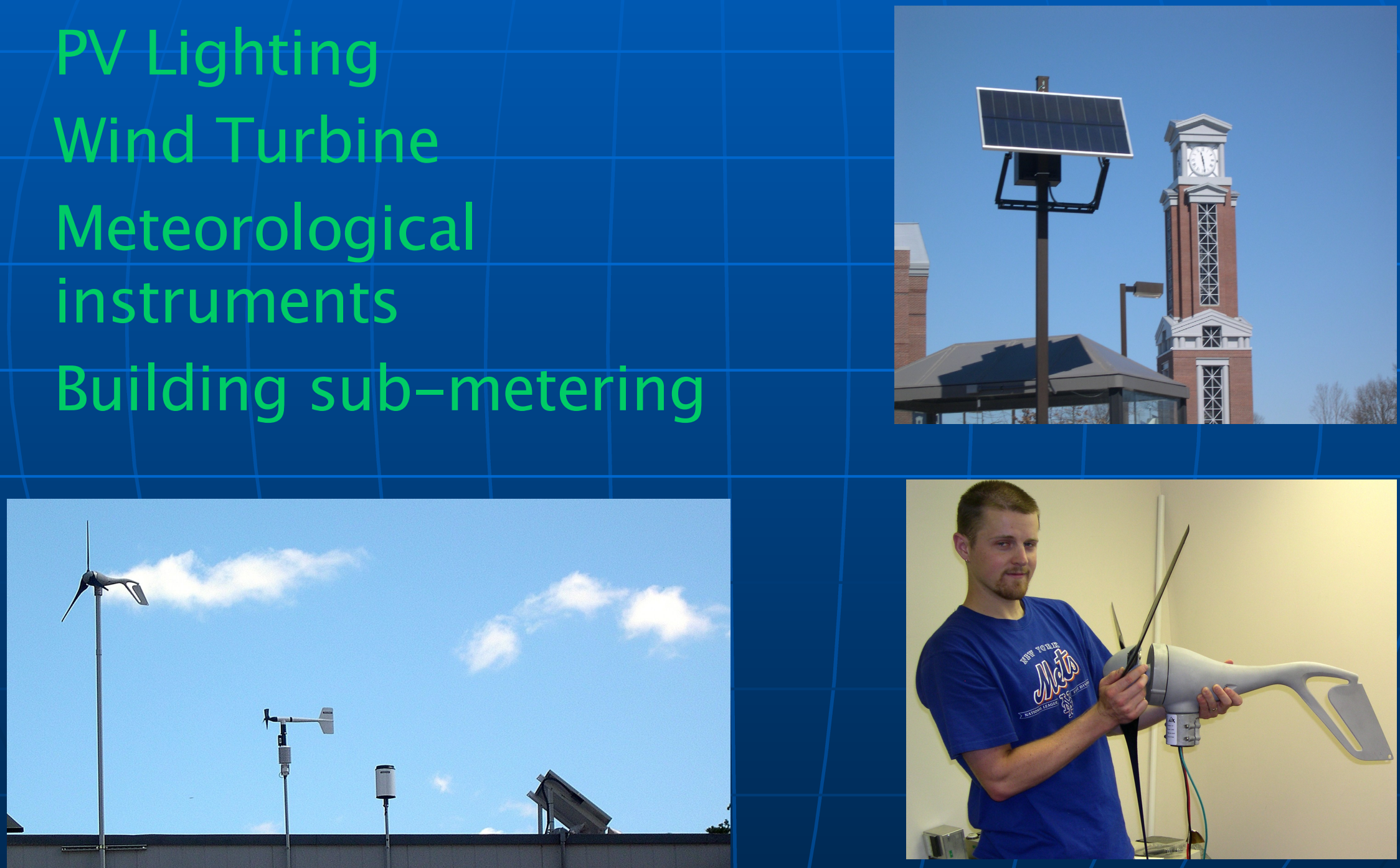


\section{Mobilizing STEM Education}

\section{http://mobilizingstem.wceruw.org}

\section{NSF- funded project}

Univ. of Wisconsin - Madison

. "Instructors in postsecondary institutions are slow to incorporate into their teaching the globally relevant resources and research-based teaching methods already developed"

- "Research indicates that without changes to structural and cultural features of postsecondary institutions, particularly research universities, these problems of uptake and scale-up will not be solved"

-"We believe that reliance on (a) the grassroots efforts of individuals, campus groups, and networks; (b) traditional modes of disseminating intellectual knowledge; or (c) people's "natural" inclination to adopt new practices that are supported by convincing evidence about change is fundamental to our slow progress"

--Has advisory board - Ecology rep. - David Blockstein is Senior Scientist with the National Council for Science and the Environment (NCSE), 
Council of Colleges of Arts \& Sciences 44th Annual Meeting

Council of Colleges of Arts \& sciences ber 11-14, 2009

\section{Session Q: Sustainability in Higher Education}

This panel will explore: why Higher Education has lagged behind the private sector; why the business world embraces sustainability and the need for "Green" jobs; how developing curricula in sustainability can foster innovative pedagogical techniques focused on interdisciplinary teaching and learning, the challenges of developing sustainability programs at universities: breaking down academic "silos;", and opportunities for external funding in sustainability. 


\section{Resources for Sustainability Education - K-12 level and Teacher Preparation}

U.S. Partnership for Education for Sustainable Development

www.uspartnership.org - 10/2008 summit - developed $\mathrm{K}-12$ sustainability education standards organization led by Dr. Debra Rowe, based at Oakland Community College - Ph.D. Business - many publications

Components include: intergenerational responsibility, interconnectedness, ecological systems, economic systems, social and cultural systems, personal action and collective action 


\section{Resources for integrating sustainability into higher education institutions}

Five major national efforts to integrate sustainability into higher education institutions' mission and planning, curricula, research, student life, facilities, purchasing and operations.

DANS - Disciplinary Associations Network for Sustainability

HEASC - Higher Education Associations Sustainability Consortium

AASHE - Association for the Advancement of Sustainability in Higher Education

ACUPCC - American College and University Presidents' Climate Commitment

Green Jobs - multiple resources, Consortium for Education in Renewable Energy Technology 
What can ESA do to promote infusion of ecology into sustainability curriculum and research?

Develop a statement on how ecologists can influence change in sustainability education at higher education institutions

Develop collaborations with current federally-funded national projects to infuse ecology into STEM education reform on sustainability issues

Develop a clearinghouse of best practices in infusion of sustainability into ecology education and ecology research at the college and $\mathrm{K}-12$ levels to guide ESA members 